\title{
Framing of China Pakistan Economic Corridor (CPEC) in Elite Press of India and Afghanistan (2015-2017)
}

\author{
Shahbaz Aslam ${ }^{1}$, Arshad $\mathrm{Ali}^{2}, \&$ Muhammad Farooq ${ }^{2}$ \\ ${ }^{1}$ School of Media \& Communication Studies, University of Central Punjab, Lahore, Pakistan \\ ${ }^{2}$ Center for Media \& Communication Studies, University of Gujrat, Pakistan \\ Correspondence: Shahbaz Aslam, School of Media \& Communication Studies, University of Central Punjab, \\ Lahore, Pakistan. Tel: 92-313-751-5722. E-mail: shahbaz_vu@yahoo.com
}

Received: May 28, 2020

Accepted: June 9, $2020 \quad$ Online Published: June 17, 2020

doi:10.5539/ass.v16n7p57

URL: https://doi.org/10.5539/ass.v16n7p57

\begin{abstract}
\$1 trillion Belt Road Initiative (BRI)'s China-Pakistan Economic Corridor (CPEC) component is a dimensional shift in Sino-Pak relations and a conception of shared future being heralded as the game changer for Pakistan as well as for the whole region. As a nodal part of the China's ambitious Belt \& Road Initiative that envisage to improve connectivity on transcontinental scale by connecting China to Central and Eastern Europe, the Middle East and Africa, the CPEC has come under attention of international media, policy makers, economists and academicians. This study discusses the framing of CPEC in press of India and China. India being territorial neighbors and China being the investor shares certain interests, reservations and apprehensions related to CPEC. Two English newspapers from China (China Daily \& Global Times) and India (Indian Express \& The Hindu) were selected and all the news and editorials related to CPEC were analyzed for the period of 2015-2017. Finding reveals that India's press is covering CPEC more in terms of strategic and conflict perspective rather than infrastructure and connectivity aspects. However, the Chinese press covers CPEC in broader context of BRI and globalization hence connectivity, development, strategic value and economic paybacks are the dominant frames. Moreover, framing of CPEC varies over the time in the press of India and China. Study suggests that policy making is needed to reduce the negative stance and communication differences of international press towards CPEC. Findings imply that Pakistan should made efforts to develop better relations with neighboring countries by engaging them with CPEC as a project of development, mutual benefit and regional integration.
\end{abstract}

Keywords: Framing, Sino-Pak relations, Content analysis, News sources, regional development

\section{Introduction}

The launch of Belt and Road Initiative is a foreign policy initiative of China. BRI is aimed to enhance connectivity and cooperation on a transcontinental scale and is considered as a major shift in China's foreign policy as in the words of a former Chinese leader Deng Xiaoping's, it is important to hide your strength and bide you time (Hart, 2015). BRI which is called as "yi dai yi lu" in Chinese language was first proclaimed in 2013 by Chinese President Xi Jinping as a transnational connectivity plan purposefully being constructed for enhance trade through infrastructure building as well as shared investment among China and more than 68 countries across globe which is going to have serious consequences for the world in perspective of socio-economic development and progress as the countries currently participating in BRI account for more than 30 percent of the global GDP, 62 percent of the world population and 75 percent of energy reserves.

The BRI's road actually describes the maritime routes running from China to Europe through Southeast Asia and Africa. The belt, on the other hand refers to overland routes stretching through Central Asia to Europe. There are several infrastructure projects involving roads, railways and bridges which is just a single component of BRI as the initiative meant a lot for China to just infrastructure development.

BRI is a vision to build several economic corridors. These corridors are meant to connect several countries except China Pakistan Economic Corridor (CPEC) which has been developed for Pakistan. CPEC stands unique in BRI as the Pakistan's position in this gigantic development initiative is seen as the buckle in the belt. This corridor would link China's far western region of Xinjiang to Pakistan's port city of Gwadar. This is an important trading route for China, mainly because of the Pakistan's geo location lies between China and its energy suppliers in Africa and the Middle East. China is a great economy and has a huge craving for energy and is the 
leading as and is the world's largest oil and gas importer. The country is fighting to keep the economy afloat, and some are worried that Pakistan's debts to China may ultimately hurt those efforts.

\subsection{China Pakistan Economic Corridor (CPEC)}

China-Pakistan Economic Corridor (CPEC) is a flagship project of the "One Belt One Road" vision of China (Wolf, 2016) which extends from the Baltics to Southeast Asia and from China to Africa (Khatak, 2016). President Jinping highlighted the aim of "One Belt One Road" or "The Silk Road Economic Belt" in his speech in September 2013 as to revive the old Silk Road that will connect China, Middle East and Europe through Central Asia (Szczudlik-Tatar, 2013). Later in the month October 2013 he further elaborated the initiative by highlighting its second part i.e. the Maritime Silk Road (MSR) or the 21st century Maritime Silk Route Economic Belt (Arase, 2015). He further expressed strategy to accomplish this initiative by establishment of new financial institutions hence resulted in establishment of US $\$ 100$ billion Asian Infrastructure and Investment Bank (Elek, 2014) and the US $\$ 40$ billion New Silk Road Fund (Chhibber, 2015).

CPEC is not only a setup of highways and railways that is being built for promoting trade by interlinking Kashgar and Gwadar but is also an economic reforms paradigm that will envisage wide range of development projects in Pakistan's those areas which have seen comparatively little economic growth. CPEC's infrastructure development agenda includes network of roads, rails, bridges, industrial zones and power generation (Ansari, 2017) while the in a broad development spectrum it is going to revamp the economic and strategic environment of the region. It is a mega infrastructural development plan with no parallel in the history of Pakistan. China associates high importance to CPEC by considering it as a first project being funded through China's Silk Road Fund establish in 2014 with a $\$ 40$ billion pledge from Chinese state institutions which can be further understood by the addition of this project as a component of 13th five-year development plan.

The geostrategic location of Pakistan is very unique and important (Sahir \& Qureshi, 2007) as the country shares its eastern side border 'Radcliffe Line' with India, with China on northern side while the Western fronts include the boundaries of 'Gold Smith Line' with Iran and 'Durand Line' with Afghanistan where one kilometer thin Wahkhan strip kept the Soviet Union away from Pakistani frontiers. The unique geo location of Pakistan positioned Pakistan at the doorway of the strategic Persian Gulf a corridor for $65 \%$ world's oil transportation. Owing to this unique geographical location as the gateway to Central Asia and access route of World Powers into land-locked Afghanistan, Pakistan is under direct influence of 'New Great Game' and the 'Global War on Terrorism'.

\subsection{CPEC and India}

Bilateral relations among Pakistan and India are not so pleasant rather conflicting since from the partition of Sub continent due to certain disputes historically inherited disputes. Among number of contradictory issues, one of the major hurdles towards the normalization of relations among both the countries is Kashmir since from the very day of sub-continent partition (Pandian, 2005). Both the countries often attributed one another interfering to their internal and external frontlines. India blamed Pakistan for supporting independence movement of Kashmir while Pakistan often claimed proofs regarding involvement of Indian intelligence agencies in Baluchistan as well as terrorist attacks in Pakistan (Khatri \& Kueck, 2003).

India is viewing $\mathrm{CPEC}$ as a project to undermine the regional position. There are number of Indian government officials who have expressed their concerns over the CPEC since the project announced. Pakistan and China are willing to see India as partner in this mega project of development but yet India did not respond towards CPEC in positive manner rather striving for alternate options. The joining of India will definitely yield development of India as already this project got endorsement from sixty countries hence India has this global opportunity which will not only benefit the region economically but will also boost regional peace and stability. Being geographically connected, there are various transport and economic linkages already exists between India and Pakistan, which can be revived and developed under the umbrella of CPEC (Ranjan, 2015).

\section{Significance of the Study}

CPEC is considered as a rudimentary component of the OBOR Initiative and has been given great importance by Pakistan and China. CPEC aimed at beginning of a new era of development and progress. This study provides an opportunity to see the CPEC project through the lens of the press of China and India. This research would be useful to understand the media frames that are being employed by the elite press of India and China hence will develop an insight about CPEC. This study will also help the media institutions of Pakistan and China to enhance collaboration for better understanding, promoting positive features of the project among the people of China and Pakistan as well as to coup with the arguments raised by the international media. 


\section{Statement of the Problem}

The present study is has been designed to investigate how the elite press of India is framing the CPEC. The study will also examine the extent of coverage given to this project in context with the Pakistan-China relations as well as in the wider perspective of the One Belt One Road initiative. This study explores how the news media of India utilized sources of news to build specific narrative in relation with CPEC coverage. The study is focused on both news and editorials of the selected newspapers for the time period ranging from April 2015 when the project was launched to December 2017 which was the deadline for the completion of the first phase of the project.

\section{Objectives of the Study}

Keeping in view the problem statement discussed above and to measure extent of coverage, perception and perspective towards CPEC and to know the patterns of the frames used as well as selection of sources by the print media of the India, the study mainly aims to measure and highlight framing of CPEC in the coverage of newspapers of India. Study also highlights the selection, utilization and the effects of news sources on the framing of CPEC in the selected newspapers. The study further aims to assess the changes in stance of India towards CPEC over time through news framing. These objectives are quite significant and are aimed to provide assistance to the governments of Pakistan and China towards better policy formulation and planning to make the project more secure. This study is also important for the media institutions of Pakistan and China to enhance collaboration for better understanding and promoting positive image of the project.

\section{Research Questions}

RQ 1. To what extent CPEC is being covered by the newspapers of India and China?

RQ 2. Which frames are being used to cover CPEC by the newspapers of India and China?

RQ 3. How frames are being used to cover CPEC by the newspapers of India and China?

RQ 5. Which sources of information are being incorporated by the newspapers of India and China to cover CPEC?

RQ 6. Is there any variance of sources of information among the press of India and China?

\section{Theoretical Framework}

Framing is an important device which is being employed by the media to fulfill certain objectives. The interests of elite are secured and media tend to secure profit of media owners by focusing on more emotional details rather than contextual information of an issue. Media tend to protect the national interest in the context of international arena of communication by forwarding national policies and agenda. CPEC is a project of regional growth and connectivity which will transform the traditional trade and development concepts, hence regional countries have shown great interest towards this project especially countries sharing direct geographical boundaries with Pakistan. The determinants of international news coverage include foreign relations with other countries, geo-economic relations, socio-political environment and cultural as well as ideological differences and disputes. Economic interest considered as most important in international news coverage of events and issues.

The origin of the Framing theory can be attributed to Walter Lippman and his thesis; "The world outside and the pictures in our heads" (Lippmann, 1922). He was the first scholar to introduce the concept of how the media can construct a simple frame through which the audience can more easily interpret events. The development of Framing as an analytical technique was introduced by Goffman (1974) a renowned social psychologists, Entman (1991) and Gitlin (1980) with the aim to elucidate the mass media's role in defining public issues. With the development of the mass communication as an independent field of study, "framing" is now considered as an established concept in the field of mass communication studies yet there is no established or universally accepted definition of the framing available. According to Entman (1993),

"To frame is to select some aspects of a perceived reality and make them more salient in a communicating text, in such a way as to promote a particular problem definition, causal interpretation, moral evaluation, and/or treatment recommendation for the item described" (p. 52).

According to Entman (1991) "frames are information-processing schemata ( p. 7) that works by emphasizing certain pieces of reality and omit certain others"(p. 53). Entman (1993) further elaborates frames as presence or absence of certain key words in the text (p. 52). Hence certain kind of information become salient through the use of specific key words and repetition or keep the reality concealed by keeping it at salient position in the semantic structure of the news content. Similarly, there are certain pieces of information that got prominence by association with specific symbols that are culturally familiar (p. 53). Media frames do not speak for themselves, but the way in which information is ordered and narrated has an effect on how opinions are formed. 


\section{Methodology}

In the arena of communications research, the theory of framing has given birth to framing analysis, a content analysis method in which researchers analyzes the frames embedded in the news texts. It is an established method to gauge and assess the communication differences and the way journalists angle a news story. By applying framing analysis, Luther and Zhou (2005) comparatively analyzed Chinese and U.S. media coverage of SARS and concluded that newspapers in both countries used similar frames, yet positive stance has been adopted by the Chinese as compared to the U.S. newspapers who tend to apply conflict frame (p. 866). Framing analysis has also been applied to look at coverage of antiwar protests of the U.S.-Iraq War both exclusively in the news media of U.S (Dimitrova \& Strömbäck, 2005; Klein, Byerly, \& McEachern, 2009; Nevalsky, 2015), as well as in other countries 'elite newspapers (Aday, Livingston, \& Hebert, 2005; Hayes \& Guardino, 2010; Peng, 2008).

In present study, we rest upon the quantitative content analysis to assess the overall coverage and frames in the news and editorials. According to Van Gorp (2007, pp. 72-73) quantitative techniques are more appropriate to examine trends in large data sets. Examining the text through content analysis whether qualitative or quantitative way, helps researchers to gain "new insights" and improves understanding about the issues under study (Krippendorff, 2013). There are number of different methodological approaches to detect and measure media frames i.e. a linguistic approach, a hermeneutic approach, a manual holistic approach, a computer-assisted approach, and a deductive approach. This study is based on framing of CPEC which is associated with regional connectivity and development hence no previous studies found that can be applied to frame measurement related to this particular project, hence manual holistic approach seems more appropriate to detect and measure the frames in media text of the Indian press.

\subsection{Sample}

The sample is the editorials and news of the selected newspapers i.e. The Hindu \& Indian Express from India while Global Times and China Daily selected from China. News and editorials of these newspapers were analyzed from April 2015 to December 2017.

\subsection{Unit of Analysis}

Unit of analysis for this study is the paragraph.

\subsection{Instrument}

While comparing the quantitative and qualitative methods of content analysis and analyzing the definition of various communication scholars it comes to the surface that along with certain differences there are number of categories available which are considered as predefined codes for quantitative analysis, while the other part of the codes emerged in an interactive process of reading and re-reading of the communication text. Here in this study we used quantitative content analysis therefore we developed a coding sheet according to the previous literature on framing studies i.e. generic categories as well as categories emerged out of the data through inductive process.

Four graduates from the field of journalism were trained for the coding. An explicit written protocol was developed with detail set of guidelines to instruct the coders about assigning of values against categories derived. A pilot study was conducted on a sub-set sample of 5 editorials and 40 news stories to ensure the inter-coder reliability. It was obtained 0.83 by employing Cohen Kappa measurement.

\section{Analysis}

This study sought to determine the intensity of news coverage related to CPEC by the press of the India and China. The study further aimed to measure how specific sources are being utilized to promote and develop a specific narrative about CPEC. The study also sought to measure if there is any changes happened towards frame implied and tone over time by the Indian and Chinese press.

Table 1. No. of News Stories by Newspapers

\begin{tabular}{cccccccc}
\hline \multirow{2}{*}{ Newspaper } & \multirow{2}{*}{ Country } & \multicolumn{3}{c}{ News Stories } & \multicolumn{3}{c}{ Editorials } \\
\cline { 3 - 7 } & & 2015 & 2016 & 2017 & 2015 & 2016 & 2017 \\
\hline Indian Express & India & 26 & 150 & 235 & 03 & 01 & 05 \\
The Hindu & India & 24 & 41 & 64 & 01 & 06 & 04 \\
China Daily & China & 42 & 43 & 87 & 04 & 02 & 07 \\
Global Times & China & 64 & 83 & 144 & 04 & 04 & 05 \\
\hline
\end{tabular}


Table 1 reveals Indian Express published 411 news stories related to CPEC with 09 editorials and The Hindu newspaper printed 129 news stories and 11 editorials highlighting issues related to CPEC while Chinese press gave comparatively high coverage to CPEC by publishing 463 news stories and 26 editorials.

Table 2. Differences in CPEC framing in the Newspapers of India and China

\begin{tabular}{ccccccc}
\hline \multicolumn{7}{c}{ Name of The Newspaper * Master Frames Crosstabulation $^{\text {a }}$} \\
\hline \multirow{2}{*}{$\begin{array}{c}\text { Name of The } \\
\text { Newspaper }\end{array}$} & $\begin{array}{c}\text { Economic } \\
\text { Consequences }\end{array}$ & Strategic & $\begin{array}{c}\text { Foreign } \\
\text { Relations }\end{array}$ & Conflict & Develop-ment \\
\cline { 2 - 7 } & 57 & 100 & 83 & 256 & 90 & 586 \\
\hline Indian Express & 15 & 51 & 37 & 63 & 27 & 193 \\
The Hindu & 132 & 201 & 192 & 114 & 209 & 868 \\
China Daily & 350 & 459 & 367 & 188 & 610 & 2012 \\
Global Times & 554 & 811 & 679 & 621 & 936 & 779 \\
Total & a. Country of Newspaper = India, China \\
& \multicolumn{7}{c}{}
\end{tabular}

Note: $d f=4, X^{2}=14.03, p=.01$

Table 2 shows the results of Chi-square test, which shows that Indian Express and The Hindu used different frames to cover CPEC. Although both newspapers, covered conflict frame more, yet The Hindu also makes strategic frames more prominent to cover CPEC. In this way, it reveals that there are differences in the framing of Indian Express and The Hindu. China Daily and Global Times heavily focused on development, economic consequence and strategic nature of the project.

Table 3. Differences in CPEC Framing Over time by Indian Press

\begin{tabular}{|c|c|c|c|c|c|c|}
\hline \multirow{3}{*}{$\begin{array}{l}\text { Year of the } \\
\text { Content }\end{array}$} & \multicolumn{6}{|c|}{ Year of the Content * Master Frames Crosstabulationa } \\
\hline & \multicolumn{5}{|c|}{ Master Frames } & \multirow[t]{2}{*}{ Total } \\
\hline & $\begin{array}{c}\text { Economic } \\
\text { Consequences }\end{array}$ & Strategic & $\begin{array}{c}\text { Foreign } \\
\text { Relations }\end{array}$ & Conflict & Development & \\
\hline 2015 & 8 & 15 & 10 & 28 & 16 & 77 \\
\hline 2016 & 15 & 51 & 38 & 117 & 32 & 253 \\
\hline 2017 & 49 & 85 & 72 & 174 & 69 & 449 \\
\hline Total & 72 & 151 & 120 & 319 & 117 & 779 \\
\hline \multicolumn{7}{|c|}{ a. Country of Newspaper = India } \\
\hline
\end{tabular}

Note: $d f=8, X^{2}=10.37, p=.24$

Table 3 shows the results of Chi-square test, which indicates that framing of CPEC in Indian press don't vary with the passage of time. The coverage of CPEC has increased from year to year in Indian press. In 2017, there were more coverage of CPEC than 2015 and 2016. Moreover, the pattern of coverage has also similarity from year to year.

Table 4. Differences in CPEC Framing Over time by Chinese Press

\begin{tabular}{|c|c|c|c|c|c|c|c|}
\hline \multicolumn{8}{|c|}{ Year of the Content * Master Frames Crosstabulation ${ }^{a}$} \\
\hline \multirow[b]{2}{*}{ Year } & \multicolumn{6}{|c|}{ Master Frames } & \multirow[t]{2}{*}{ Total } \\
\hline & $\begin{array}{c}\text { Economic } \\
\text { Consequences }\end{array}$ & Cultural & Strategic & $\begin{array}{c}\text { Foreign } \\
\text { Relations }\end{array}$ & Conflict & Develop-ment & \\
\hline 2015 & 119 & 20 & 235 & 157 & 81 & 193 & 805 \\
\hline 2016 & 129 & 16 & 160 & 137 & 60 & 249 & 751 \\
\hline 2017 & 234 & 22 & 265 & 265 & 161 & 377 & 1324 \\
\hline Total & 482 & 58 & 660 & 559 & 302 & 819 & 2880 \\
\hline \multicolumn{8}{|c|}{ a. Country of Newspaper $=$ China } \\
\hline
\end{tabular}

Note: $d f=10, X^{2}=44.36, p=.01$

Table 4 shows the result of Chi-square test, which indicates that framing of CPEC in Chinese press varies with the passage of time. The coverage of CPEC has increased from year to year in Chinese press. In 2017, there were 
more coverage of CPEC with focus to developmental frames than 2015 and 2016.

Table 5. Differences in Slant of CPEC Framing Over time by Indian Press

\begin{tabular}{cccccc}
\hline Year & $\mathrm{N}$ & Mean & SD & F $(2,776)$ & Sig. \\
\hline 2015 & 77 & 1.70 & .650 & & \\
2016 & 253 & 1.68 & .657 & 2.10 & .12 \\
2017 & 449 & 1.79 & .747 & & \\
Total & 779 & 1.75 & .710 & & \\
\hline
\end{tabular}

Table 5 shows the results of one-way ANOVA. It indicates that slant of Indian press about the framing of CPEC does not vary from 2015 to 2017. CPEC was most negatively covered in all three years 2015-17 by Indian press. However, the mean score of CPEC framing is gradually increasing towards positive direction from 2015 to 17 by the Indian press.

Table 6. Differences in Slant of CPEC Framing Over time by Chinese Press

\begin{tabular}{cccccc}
\hline Year & N & Mean & SD & F (2, 2877) & Sig. \\
\hline 2015 & 805 & 2.89 & .418 & & \\
2016 & 751 & 2.91 & .402 & .211 & .81 \\
2017 & 1324 & 2.90 & .418 & & \\
Total & 2880 & 2.90 & .414 & & \\
\hline
\end{tabular}

Table 6 indicates that slant of Chinese press about CPEC does not vary from 2015 to 2017. CPEC was mostly covered positively in all three years $2015-17$ by Chinese press.

Table 7. Effect of Information Sources on CPEC Framing in Indian Press

\begin{tabular}{ccccccc}
\hline \multicolumn{7}{c}{ Sources of News * Master Frames Crosstabulation } \\
\hline & \multicolumn{7}{c}{ Master Frames } & & Total \\
\cline { 2 - 7 } Sources of News & $\begin{array}{c}\text { Economic } \\
\text { Consequences }\end{array}$ & Strategic & $\begin{array}{c}\text { Foreign } \\
\text { Relations }\end{array}$ & Conflict & Development \\
\hline Sino-Pak Governments & 35 & 55 & 47 & 65 & 66 & 268 \\
Indigenous Government & 2 & 21 & 21 & 76 & 4 & 124 \\
Other Governments & 2 & 10 & 5 & 7 & 2 & 26 \\
Sino-Pak Politicians & 1 & 1 & 1 & 2 & 2 & 7 \\
Indigenous Politicians & 3 & 0 & 1 & 7 & 0 & 11 \\
Other Politicians & 0 & 0 & 0 & 1 & 0 & 1 \\
Sino-Pak Press & 11 & 14 & 12 & 21 & 11 & 69 \\
Indigenous Press & 16 & 36 & 23 & 108 & 23 & 206 \\
Other Press & 0 & 0 & 3 & 5 & 1 & 9 \\
Sino-Pak Civil Society & 0 & 0 & 1 & 0 & 0 & 1 \\
Experts & 1 & 13 & 6 & 14 & 8 & 42 \\
Others & 1 & 1 & 0 & 13 & 0 & 15 \\
Total & 72 & 151 & 120 & 319 & 117 & 779 \\
& a. Country of Newspaper $=$ India & & & \\
\hline
\end{tabular}

Note: $d f=44, X^{2}=139.46, p=.01$

Table 7 shows the results of Chi-square test, which indicates that the framing of CPEC varies according to the sources of information which are being used to cover CPEC by the Indian press. Indian press mostly used indigenous government and indigenous press to cover CPEC. Indian government and press heavily focused on conflict and strategic frames. However, Sino-Pak governments are also making conflict frame as well as developmental frames more prominent. 
Table 8. Effect of Information Sources on CPEC Framing in Chinese Press

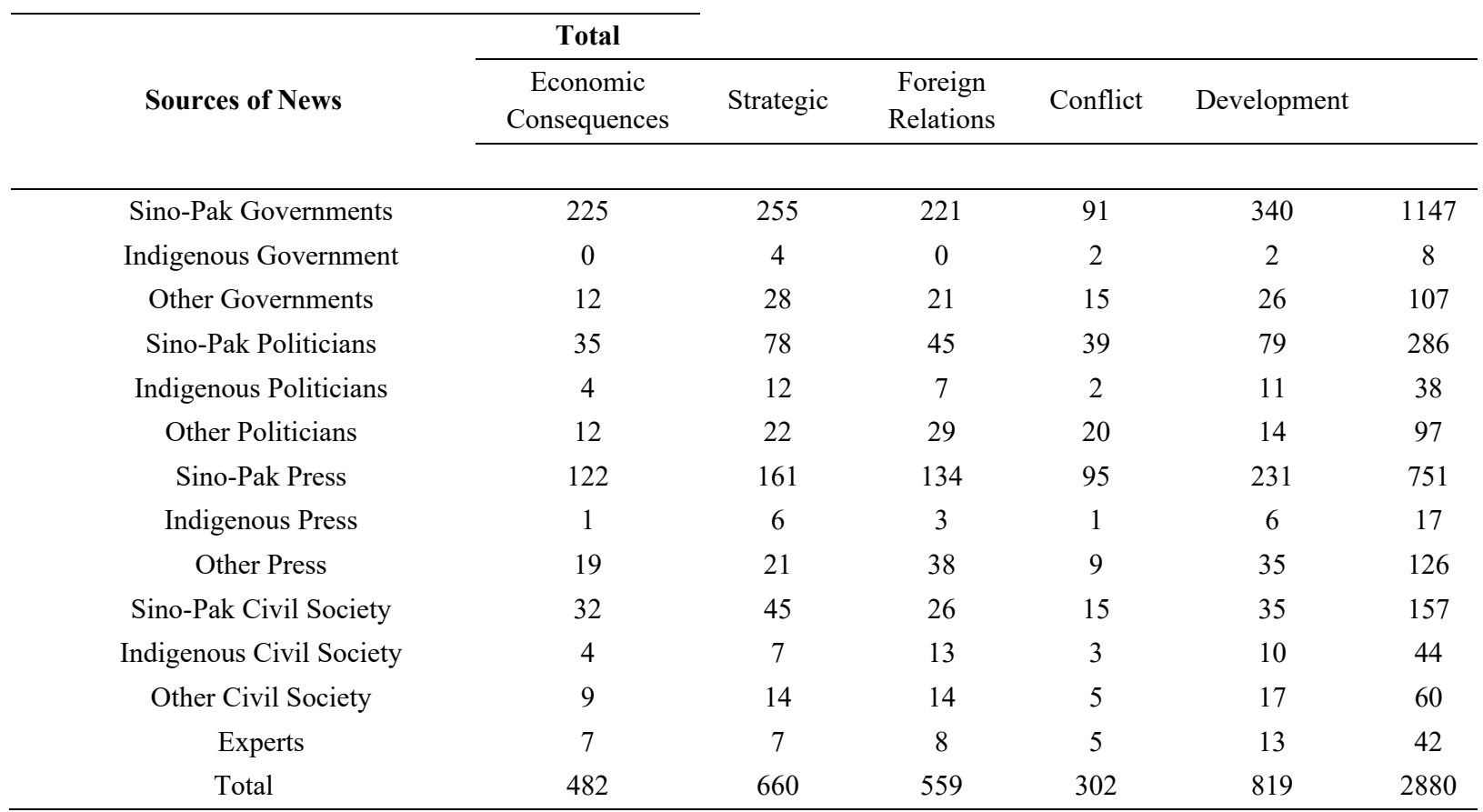

Note: $d f=60, X^{2}=158.75, p=.01$

The table 8 shows the results of Chi-square test, which indicates that the framing of CPEC varies according to the sources of information which are being used to cover CPEC by the Chinese. Sino-Pak governments heavily focused on developmental and strategic frames. However, other governments are making strategic and foreign relations more prominent. Similarly, press of other countries also highlighting foreign relations frames more prominent.

Table 9. Differences of Slant in CPEC Framing by Indian Press

\begin{tabular}{|c|c|c|c|c|c|c|}
\hline Frames & $\mathrm{N}$ & Mean & SD & $\mathrm{F}(4,774)$ & Sig. & Partial $\eta^{2}$ \\
\hline Strategic & 151 & 1.94 & .723 & & & \\
\hline Foreign Relations & 120 & 2.00 & .674 & & & \\
\hline Conflict & 319 & 1.34 & .565 & & & \\
\hline Development & 117 & 2.21 & .580 & & & \\
\hline Total & 779 & 1.75 & .710 & & & \\
\hline
\end{tabular}

Table 9 presents the results of One-way ANOVA. It indicates that there are significant differences in the slant of frames, which are being used by Indian press. It shows that all the frames are being used from negatively to neutrally, however, slant of developmental frames ranges from neutral to positive. It represents that conflict and strategic frames are portrayed highly negative by the Indian press. Economic consequences, foreign relations and developmental frames are portrayed in positive direction. Further it shows that after reaching statistical significance, the actual difference in mean scores between the groups was very large. The effect size, calculated using eta squared, was .24.

Table 10. Differences of Slant in CPEC Framing by Chinese Press

\begin{tabular}{ccccccc}
\hline Frames & $\mathrm{N}$ & Mean & SD & F (5, 2874) & Sig. & ${\text { Partial } \eta^{2}}^{2}$ \\
\hline Economic Consequences & 482 & 2.96 & .225 & & & \\
Cultural & 58 & 2.93 & .368 & & & \\
Strategic & 660 & 2.95 & .307 & & .01 & .06 \\
Foreign Relations & 559 & 2.82 & .551 & 40.19 & & \\
Conflict & 302 & 2.64 & .724 & & \\
Development & 819 & 2.97 & .219 & & \\
Total & 2880 & 2.90 & .414 & & \\
\hline
\end{tabular}


Table 10 presents the results of One-way ANOVA. It indicates that there are no more significant differences in the slant of frames, which are being used by Chinese press. It shows that all the frames are being used highly positive. It represents that Cultural, developmental, trade \& economic frames are portrayed highly positive and strategic and foreign relations frames are also presented positively. However, conflict frames are portrayed ranges from negative to neutral. Further it shows that after reaching statistical significance, the actual difference in mean scores between the groups was found at medium level. The effect size, calculated using eta squared, was .06 .

\section{Discussion and Conclusion}

We are living in an era of globalization where global events often have regional and national implications. CPEC being a regional connectivity projects attracted huge interests from regional countries as it is going to reshape the regional as well as global trade dynamics in coming decades. Regional countries have their reservation and expectation towards this massive development project directly associated with regional, territorial and political ambitions. International relations and global communication contexts are not static. They are continuously changing. Therefore, communication scholars often study news framing over time to find a comprehensive picture of the framing (Dimitrova, 2006; Shou, 2012). Our study also supports these findings of previous studies.

The data analysis reveals that press of India (Indian Express and The Hindu) covers CPEC in terms of territorial conflict rather than development, regional connectivity and progress. The other heavily used frame by the Indian press is strategic frame which aimed at highlight the strategic aspects of CPEC rather than it developmental overview to make it more controversial and doubtful for world. However, Chinese press focused more on development and regional prosperity.

Press framing heavily relies on sources of information as the diverse news sources plays a key role in constructing aspects or meanings of the events (Kim \& Jahng, 2016). The press coverage related to certain event often got manipulated by the reporters by relying upon exclusively and uncritically upon certain authoritative sources of news (Pfund \& Hofstadter, 1981). Moreover, the selection of sources is implied to create imbalances, biased and distorted image of nations in international communication (Saleem, 2007; Wanta, Golan, \& Lee, 2004). In present study, we also found that the selection of specific sources in covering news related to a specific event has significant contribution towards framing of that event. The data analysis reveals that in terms of source selection related to CPEC news, India press heavily relies on their own sources and Indian government as compared to Pakistani or Chinese sources which can interpreted building a specific narrative about CPEC by ignoring the real picture about the project. Chinese press quotes official sources heavily along with Sino-Pak politicians and Sino-Pak press.

However, the Indian press is realizing the importance of this mega project and a shift although not so strong yet can be witnessed over the rigid stand towards CPEC towards more rational approach as indicated by an editorial publish in "The Hindu" on 16-05-2017 titled "Don't shut the door on diplomacy over "China's Belt and Road Initiative" stating importance and benefits associated with the project.

The analysis reveals that despite of certain apprehension about CPEC, the Indian media is realizing and voicing the importance of the project which can be further strengthen by disseminating and promoting importance of the project towards regional progress, development, connectivity, human development and resource distribution to cope with the prevailing poverty and disparity.

The CPEC raised hopes toward a developed Pakistan with improved connectivity, infrastructure, business opportunities, human resource development and better living standard for the people of Pakistan. However, this can be achieved after successful implementation of the CPEC projects which then be called a game changer rather fate changer in true sense for Pakistan and for the region as well. The positive thing is that CPEC as a national development project is owned by the all the stakeholder including civilian and military leadership who are willing ensure timely implementation of all the projects.

\section{References}

Aday, S., Livingston, S., \& Hebert, M. (2005). Embedding the truth: A cross-cultural analysis of objectivity and television coverage of the Iraq War. Harvard International Journal of Press/Politics, 10(1), 3-21. https://doi.org/10.1177/1081180X05275727

Ansari, K. M. (2017, 13-09-2017). China Pakistan Economic Corridor, Newspaper Article. Pakistan Observer. Retrieved from https://pakobserver.net/china-pakistan-egonomic-gorrtdor/

Arase, D. (2015). China's Two Silk Roads Initiative: What It Means for Southeast Asia. Southeast Asian Affairs, 2015(1), 25-45. 
Chhibber, A. (2015). China's One Belt One Road Strategy: The New Financial Institutions and India's Options'.

Dimitrova, D. V. (2006). Episodic frames dominate early coverage of Iraq War in the NYTimes. com. Newspaper Research Journal, 27(4), 79-83. https://doi.org/10.1177/073953290602700406

Dimitrova, D. V., \& Strömbäck, J. (2005). Mission accomplished? Framing of the Iraq War in the elite newspapers in Sweden and the United States. Gazette (Leiden, Netherlands), 67(5), 399-417. https://doi.org/10.1177/0016549205056050

Elek, A. (2014). The potential role of the Asian Infrastructure Investment Bank. Paper presented at the East Asia Forum.

Entman, R. M. (1991). Symposium framing US coverage of international news: Contrasts in narratives of the KAL and Iran air incidents. Journal of communication, 41(4), 6-27. https://doi.org/10.1111/j.1460-2466.1991.tb02328.x

Entman, R. M. (1993). Framing: Toward clarification of a fractured paradigm. Journal of communication, 43(4), 51-58. https://doi.org/10.1111/j.1460-2466.1993.tb01304.x

Gitlin, T. (1980). The whole world is watching. Berkeley (Vol. 11). USA.

Goffman, E. (1974). Frame analysis: An essay on the organization of experience. Harvard University Press.

Hart, M. (2015). Assessing American Foreign Policy Toward China. Center for American Progress, 29.

Hayes, D., \& Guardino, M. (2010). Whose views made the news? Media coverage and the march to war in Iraq. Political Communication, 27(1), 59-87. https://doi.org/10.1080/10584600903502615

Khatak, R. (2016, 24-08-2016). OBOR and CPEC, Column. The Dawn. Retrieved from http://www.dawn.com/news/1279479

Khatri, S. K., \& Kueck, G. W. (2003). Terrorism in South Asia: Impact on development and democratic process. Shipra Publications.

Kim, Y., \& Jahng, M. R. (2016). Who frames nuclear testing? Understanding frames and news sources in the US and South Korean news coverage of North Korean nuclear testing. The Journal of International Communication, 22(1), 126-142. https://doi.org/10.1080/13216597.2015.1076732

Klein, A. G., Byerly, C. M., \& McEachern, T. M. (2009). Counterframing public dissent: An analysis of antiwar coverage in the US media. Critical Studies in Media Communication, 26(4), 331-350. https://doi.org/10.1080/15295030903176658

Krippendorff, K. (2013). Commentary: A dissenting view on so-called paradoxes of reliability coefficients. Annals of the International Communication Association, 36(1), 481-499. https://doi.org/10.1080/23808985.2013.11679143

Lippmann, W. (1922). The world outside and the pictures in our heads. Public opinion, 4, 1-22.

Luther, C. A., \& Zhou, X. (2005). Within the boundaries of politics: News framing of SARS in China and the United States. Journalism \& Mass Communication Quarterly, 82(4), 857-872. https://doi.org/10.1177/107769900508200407

Nevalsky, E. C. (2015). Developing terrorism coverage: variances in news framing of the January 2015 attacks in Paris and Borno. Critical Studies on Terrorism, 8(3), 466-477. https://doi.org/10.1080/17539153.2015.1096656

Pandian, S. (2005). The political economy of trans-Pakistan gas pipeline project: Assessing the political and economic risks for India. Energy Policy, 33(5), 659-670. https://doi.org/10.1016/j.enpol.2003.09.011

Peng, Z. (2008). Framing the anti-war protests in the global village: A comparative study of newspaper coverage in three countries. International Communication Gazette, 70(5), 361-377. https://doi.org/10.1177/1748048508094293

Pfund, N., \& Hofstadter, L. (1981). Biomedical innovation and the press. Journal of communication, 31(2), 138-154. https://doi.org/10.1111/j.1460-2466.1981.tb01237.x

Ranjan, A. (2015). The China-Pakistan economic corridor: India's options. New Delhi.

Sahir, M. H., \& Qureshi, A. H. (2007). Specific concerns of Pakistan in the context of energy security issues and geopolitics of the region. Energy Policy, 35(4), 2031-2037.

Saleem, N. (2007). US media framing of foreign countries image: An analytical perspective. Canadian Journal 
of Media Studies, 2(1), 130-162.

Shou, X. (2012). Framing Tibet: A comparative study of Chinese and American newspapers, 2008-2011. https://doi.org/10.31274/etd-180810-1951

Szczudlik-Tatar, J. (2013). China's New Silk Road Diplomacy. Policy Paper, (34).

Van Gorp, B. (2007). The constructionist approach to framing: Bringing culture back in. Journal of communication, 57(1), 60-78.

Wanta, W., Golan, G., \& Lee, C. (2004). Agenda setting and international news: Media influence on public perceptions of foreign nations. Journalism \& Mass Communication Quarterly, 81(2), 364-377. https://doi.org/10.1177/107769900408100209

Wolf, S. O. (2016). The China-Pakistan Economic Corridor: An Assessment of its Feasibility and Impact on Regional Cooperation.

\section{Copyrights}

Copyright for this article is retained by the author(s), with first publication rights granted to the journal.

This is an open-access article distributed under the terms and conditions of the Creative Commons Attribution license (http://creativecommons.org/licenses/by/4.0/). 